\title{
EVALUATION OF CARDIAC INVOLVEMENT IN PATIENTS WITH PRIMARY HYPOTHYROIDISM
}

Kotha Sindhoora1, Khandeparkar Viraj², Velho G. Rachita³, Cacodcar Jagadish4

\section{HOW TO CITE THIS ARTICLE:}

Kotha Sindhoora, Khandeparkar Viraj, Velho G. Rachita, Cacodcar Jagadish. "Evaluation of Cardiac Involvement in Patients with Primary Hypothyroidism". Journal of Evolution of Medical and Dental Sciences 2015; Vol. 4, Issue 62, August 03; Page: 10747-10757, DOI: 10.14260/jemds/2015/1552

ABSTRACT: BACKGROUND: The cardiovascular system is one of the major targets of thyroid hormone action, and is a reliable marker of peripheral thyroid hormone action. It is sensitive enough to detect the effects of thyroid hormone deficiency at tissue level not only in patients with overt but also in individuals with mild thyroid failure. AIMS AND OBJECTIVES: Investigate clinical cardiovascular and echocardiographic abnormalities in newly detected hypothyroid patients, correlate them with the severity and assess the response to treatment. RESULTS: Heart rate was significantly associated with grade of hypothyroidism. Statistically significant correlation was seen between the grade of hypothyroidism, and the echocardiographic parameters like the isovolumic ventricular relaxation time, grade of diastolic dysfunction, interventricular septum thickness and the pericardial effusion. Improvement in all these parameters was seen following replacement therapy, in patients who were followed up. CONCLUSIONS: Echocardiography is a very valuable tool in evaluation of the effects of hypothyroidism on heart and can detect earliest changes even in subclinical hypothyroidism.

KEYWORDS: Hypothyroidism, Echocardiography, Pericardial Effusion.

INTRODUCTION: The cardiovascular system is one of the major targets of thyroid hormone action, and is a reliable marker of peripheral thyroid hormone action. It is sensitive enough to detect the effects of thyroid hormone deficiency at tissue level, not only in patients with overt thyroid failure but also in individuals with milder one (Biondi and Klein, 2004). ${ }^{1}$ Hypothyroid patients, even those with subclinical hypothyroidism, have impaired endothelial function, normal/depressed systolic function, left ventricular diastolic dysfunction at rest, and systolic and diastolic dysfunction on effort, which may result in poor physical exercise capacity. There is also a tendency for the diastolic blood pressure to rise as a result of increased systemic vascular resistance (Biondi and Klein, 2004). ${ }^{1}$

Clinically there may be variable degrees of bradycardia, diastolic hypertension, narrow pulse pressure and relatively quiet precordium with decreased intensity of the apical impulse, and cold extremities. Irwin Klein, wrote in Braunwald's heart disease ${ }^{2}$ that an increase in the risk factors for atherosclerosis, including hypercholesterolemia, hypertension, and elevated levels of homocysteine, may predispose the hypothyroid individual to the accelerated and premature atherosclerosis in the coronary and systemic vascular bed. This study has been conducted to evaluate the physical effects of hypothyroidism on the heart through clinical and echocardiographic evaluation.

\section{RESEARCH QUESTIONS:}

1. What are the clinical and echocardiographic abnormalities of the heart in newly detected hypothyroid patients?

2. What are the correlations of these findings with the severity of hypothyroidism? 


\section{ORIGINAL ARTICLE}

3. What is the response after three months of replacement therapy, based on follow up echocardiography?

\section{METHODOLOGY:}

Type of study: $\quad$ Case series.

Number of patients: 50 .

Duration of Study: $\quad 1^{\text {st }}$ January 2012 to $30^{\text {th }}$ January 2013.

- Data was entered in a pretested questionnaire. Total no of points: 30

- First 10 questions related to Billewicz score.

- Next 2 questions related to pulse and blood pressure measurements.

- Next 3 categories related to systemic examination.

- 5 categories related to lab investigations.

- 1 related to grade of hypothyroidism.

- 1 related to ECG findings.

- 8 questions related to Echocardiographic parameters.

\section{Inclusion Criteria:}

1. Newly detected primary hypothyroidism.

2. Age between 18 years to 70 years.

\section{Exclusion Criteria:}

1. History of previous thyroid illness or surgery.

2. Use of drugs known to interfere with thyroid hormone metabolism. (Phenytoin, phenobarbitone, carbamazepine, carbimazole, warfarin, rifampicin, lithium, propranolol, amiodarone, glucocorticoids)

3. Abnormal renal function test.

4. Abnormal liver function test.

5. Pregnancy.

6. Patients with hypertension, diabetes mellitus, known previous heart disease, other endocrine disorders, collagen disorder.

Patients were divided into subclinical and overt hypothyroid groups which were then subdivided into a total of 5 subgroups based on the thyroid function tests.

Grade I: $\quad$ TSH level $>5 \mu \mathrm{IU} / \mathrm{ml}$ but less than $10 \mu \mathrm{IU} / \mathrm{ml}$ with normal T3 and T4.

Grade II: $\mathrm{TSH}>10 \mu \mathrm{IU} / \mathrm{ml}$ but $<20 \mu \mathrm{IU} / \mathrm{ml}$ with normal T3 and T4.

Grade III: $\mathrm{TSH}>20 \mu \mathrm{IU} / \mathrm{ml}$ with a normal T3 and T4.

Grade IV: $\mathrm{TSH}>20 \mu \mathrm{IU} / \mathrm{ml}$, low $\mathrm{T} 4<4.50 \mu \mathrm{g} / \mathrm{ml}$, T3 $>60 \mathrm{ng} / \mathrm{dl}$.

Grade V: $\quad \mathrm{TSH}>20 \mu \mathrm{IU} / \mathrm{ml}$, low T4 $<4.50 \mu \mathrm{g} / \mathrm{ml}, \mathrm{T} 3<60 \mathrm{ng} / \mathrm{dl}$.

Statistical analysis was performed using SPSS software 14.0 version (USA). Data with normal distribution were expressed as mean \pm standard deviation. For statistical analysis Pearson correlation test, Chi- Square test and Kruskal- Wallis test were used wherever appropriate, and $\mathrm{p}$ value $<0.05$ was considered to be statistically significant. 


\section{ORIGINAL ARTICLE}

RESULTS: The total number of patients studied: 50 .

$10(20 \%)$ of the subjects were males and $40(80 \%)$ were females. Their mean age was 45 years and 37 years respectively. Majority of the patients were in the age group between 19 to 50 years.

Chest X-ray revealed cardiomegaly in 4 patients of the overt hypothyroid group, of which 3 had pericardial effusion. Low voltage complexes on ECG were seen in 7 patients and this had no significant correlation with presence of pericardial effusion. Heart rate was found to be significantly

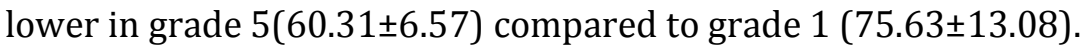

Diastolic dysfunction was measured using the parameters of Isovolumic ventricular relaxation time (IVRT), deceleration time (dt) and E/A ratio (early diastolic mitral flow velocity/late diastolic mitral flow velocity ratio). Of these statistically significant positive correlation was seen between isovolumic ventricular relaxation time and grade of hypothyroidism, and between grade of hypothyroidism and grade of diastolic dysfunction as a whole ( $\mathrm{p}$ value=0.045).

Of the 50 patients 9 patients had diastolic dysfunction, four of whom had Grade V hypothyroidism, four had Grade IV hypothyroidism and one had grade III hypothyroidism. Severe diastolic (grade III) dysfunction was seen in 2 patients; both having overt hypothyroidism (Grade V). The results proved a statistically significant worsening of diastolic dysfunction with the increasing degree of hypothyroidism.

Statistically significant correlation was also found between grade of hypothyroidism and interventricular septum thickness. An increase in interventricular septum thickness was seen in patients with overt hypothyroidism, most belonging to grade V hypothyroidism. Asymmetric septal hypertrophy was seen in 3 patients, all with grade $\mathrm{V}$ hypothyroidism. However there was no statistical significant relation of the left ventricular end diastolic and the left ventricular end systolic dimensions with grade of hypothyroidism but one patient was found to have dilated cardiomyopathy which was found to have improved after a 3month treatment with replacement therapy.

Statistically significant correlation was also found between grade of hypothyroidism and the presence of pericardial effusion and. Of the total ten patients who were found to have pericardial effusion, two had a massive one and both of them were with grade $\mathrm{V}$ hypothyroidism. Moderate pericardial effusion was found in 3 patients, and the remaining 6 patients had mild pericardial effusion.

7 patients from the study group were followed up after 3 months of starting replacement therapy and repeat Echocardiographic evaluation of the heart was performed. Improvement in all abnormal parameters was seen in them. Improvement in the diastolic dysfunction and reduction of the inter-ventricular septum thickness was seen at the follow up. One of the patients with a large symptomatic pericardial effusion showed a significant reduction of the effusion and improvement of the symptoms at the end of three months

DISCUSSION: Thyroid disorders are well known to influence the cardiovascular system. Kabadi et al, in 1993,3 said that hypothyroidism is associated with an increase in cardiovascular morbidity and patients with sub clinical hypothyroidism have a higher chance of progressing to frank hypothyroidism if not recognized early.

Pericardial effusion was the commonest abnormality seen in our study. $42.8 \%$ patients of the overt hypothyroid group had pericardial effusion as compared to 3.4\% in the subclinical hypothyroid group. These results are comparable to the results of the study conducted by Varma et al ${ }^{4}$ in 1995 where 44 patients were studied. They found significant pericardial effusion in 10 patients all of 


\section{ORIGINAL ARTICLE}

whom belonged to the overt hypothyroid group. Abdulla et $\mathrm{al}^{5}$ studied 36 patients of primary hypothyroidism and found pericardial effusion in 38.8\% of the patients on echocardiographic evaluation. They also found significant correlation between low voltage electrocardiographic complexes and TSH levels. But there was no correlation between heart rate and TSH levels. In contrast, our study showed significantly lower heart rate in patients belonging to the overt hypothyroid group.

Kerber, Sherman ${ }^{6}$ in 1975 studied a group of 33 patients of newly diagnosed myxedema and found that $10(30 \%)$ of the 33 patients had significant pericardial effusion which reduced on follow up with replacement therapy. In the present study 4 patients had cardiac enlargement on chest X-rays of which only 3 had significant pericardial effusions on echo evaluation. Small voltage complexes associated with sinus bradycardia on electrocardiograms were found in 4 patients with pericardial effusion. 3 patients with pericardial effusion had normal electrocardiograms. The other abnormalities with no statistically significant correlation seen were interventricular conduction defects, ST-T changes, $\mathrm{T}$ wave inversions in various leads.

The present study revealed a statistically significant correlation between grade of hypothyroidism and grade of diastolic dysfunction. 38\% patients of the overt hypothyroid group were found to have significant diastolic dysfunction. Only 1 patient (3.4\%) of the sub clinical hypothyroid group had significant diastolic dysfunction. The study conducted by Varma et $\mathrm{al}^{4}$ in 1995, revealed significant diastolic dysfunction in 27.27\% (6 out of 22) patients of the overt hypothyroid group and 9\%(2 out of 22) of the sub clinical hypothyroid group.

Biondi et al in $1998^{7}$ conducted a prospective case control study on 26 patients and they found that there is left ventricular diastolic dysfunction in sub clinical hypothyroidism. They found on Doppler derived indices of diastolic function, a significant prolongation of the isovolumic relaxation time (IVRT), increased A wave and reduced early diastolic mitral flow velocity/late diastolic mitral flow velocity ratio. They studied a sub group of 10 randomly selected patients who were put on replacement therapy. After 6 months of therapy, and with the normalization of the thyroid profile, significant enhancement of systolic function and a significant shortening of IVRT was seen. Reduction in A wave and increase in early diastolic mitral flow velocity/late diastolic mitral flow velocity ratio was also observed. In our study improvement in diastolic function was noted in the patients that were followed up 3 months later after instituting replacement therapy. Statistically significant correlation was also found between grade of hypothyroidism and IVRT which was one of the parameters used to measure diastolic dysfunction.

The next parameter studied was correlation between interventricular septum thicknesses with the grade of hypothyroidism. Statistically significant positive correlation between the grade of hypothyroidism and inter ventricular septum thickness was found. Asymmetric septum hypertrophy was demonstrated in 3 patients with overt hypothyroidism. In the study conducted by Varma et $\mathrm{al}^{4}$ statistically significant increase in inter ventricular septum thickness was found in patients with grade II hypothyroidism, and this was assumed to be the earliest structural change in the heart in patients with sub clinical hypothyroidism.

Rawat et $\mathrm{al}^{8}$ studied 20 hypothyroid patients and divided them into 4 groups based on treatment. Group A being untreated patients, group B being patients who have been on levothyroxine treatment for $4 \mathrm{~m}$ or longer, group $\mathrm{C}$ were patients reassessed after 6 months of treatment and group D were controls. They found an increasing trend in the interventricular wall thickness in patients of the older age group. They concluded saying that although increased symmetrical wall thickness is 


\section{ORIGINAL ARTICLE}

common, increased incidence of asymmetrical hypertrophy reported by a few investigators requires further confirmation.

In the present study end diastolic and end systolic left ventricular diameters were studied but no statistically significant correlation was found between these dimensions and the grade of hypothyroidism.

Systolic function of the heart was found to have no statistically significant correlation with the grade of hypothyroidism or the level of TSH in the present study. This is comparable to the findings of Smallridge et al $^{9}$ in 1987, and was further reinforced by studies conducted by Varma et al ${ }^{4}$ in 1995 and Mishra et al ${ }^{10}$ in 2005.

CONCLUSION: In the present study 50 hypothyroid patients divided into 5 groups based on thyroid function tests, were evaluated clinically and by echocardiography and effects of hypothyroidism on the heart were studied. $20 \%$ of the subjects were males and $40 \%$ females, most belonging to the age group of 19-50 years. No significant correlation between age, gender and grade of hypothyroidism was found in this study.

Electrocardiographic abnormalities and chest radiographs were also compared. Heart rate was found to be lower in patients with overt hypothyroidism and had the statistical correlation with the severity of hypothyroidism.

Pericardial effusion was the commonest finding, being observed in $42.8 \%$ subjects in the overt hypothyroid group, as compared to $3.4 \%$ in the sub clinical hypothyroid group. Thus a statistically significant correlation was found between grade of hypothyroidism and the presence of pericardial effusion. Follow up studies was done on 7 patients, all revealing significant resolution of the effusion after 3 months of replacement therapy with levothyroxine.

Interventricular septum thickness which was found to be higher in the overt hypothyroid group as compared to the sub clinical hypothyroid group, showed a decrease in the septum thickness to normal range at the follow up after replacement therapy.

Diastolic dysfunction was significantly associated with the grade of hypothyroidism. 2 of the subjects who had grade 3 diastolic dysfunction showed a significant improvement after replacement therapy. Isovolumic relaxation time was seen to gradually prolong with increase in grade of hypothyroidism.

In conclusion, echocardiography is a very valuable tool in evaluation of the effects of hypothyroidism on heart and can detect earliest changes even in sub clinical hypothyroidism such as diastolic dysfunction and increased interventricular septum thickness. Pericardial effusion was the commonest finding and is rarely severe causing hemodynamic compromise and almost never requires pericardiocentesis. Diastolic dysfunction is also a common finding and is also seen in patients with subclinical hypothyroidism.

\section{LIMITATIONS:}

1. Small sample size.

2. The findings of this case series study need to be further confirmed through analytical studies.

3. All the echocardiographic parameters of diastolic dysfunction were not analysed. Other dimensions of the heart were not compared. 


\section{ORIGINAL ARTICLE}

\section{REFERENCES:}

1. Biondi B, Klien I. Hypothyroidism as a risk factor for cardiovascular disease. Endocrine 2004: $24 ; 1-13$

2. Klein I, Braunwald's heart disease- A textbook of cardiovascular Medicine, 9th edition, chapter86 part X, page 1838-1839.

3. Kabadi UM. Natural course of subclinical hypothyroidism during a prolonged follow up. Archives internal medicine 1993; 153: 952-961

4. Varma R, Jain AK, Ghose T. Heart in hypothyroidism- an echocardiographic study. JAPI 1996. 44(6): 390-392.

5. Al farttoosi AJM, Abdul-Ghafour AS, Al-Zaidi AS. Cardiovascular manifestations of primary hypothyroidism. IPMJ 2012; 9(2): 113-118.

6. Kerber RE, Sherman B. Echocardiographic evaluation of pericardial effusion in Myxedema. Circulation, 1975; vol. 52: 823-827.

7. Biondi B, Fazio S, Palmeiri EA, Carella C, Panza N, Cittadini A, Bone F, Lombardi G, Sacca L. Left ventricular diastolic dysfunction in patients with subclinical hypothyroidism. J Clin Endo M. 1999; 84: 2064-2067.

8. Rawat B, Satyal A. an echocardiographic study of changes in hypothyroidism and the response to treatment. KUMJ 2003; vol. 2 no. 3: 182-187.

9. Smallridge RC, Goldman MH, Raines K, Nostrand JS: Rest and exercise left ventricular function in hypothyroidism- American Journal Cardiology. 1987; 60: 929-931.

10. Mishra TK, Routray SN, Behera M. Left ventricular dysfunction in patients with subclinical hypothyroidism and its reversibility after hormone therapy. JAPI 2005, 53: 943-946.

\begin{tabular}{|c|c|c|c|c|c|c|}
\hline \multicolumn{2}{|c|}{$\begin{array}{c}\text { Grade of } \\
\text { hypothyroidism }\end{array}$} & \multicolumn{3}{|c|}{ ECG changes } & \multirow{2}{*}{\multicolumn{2}{|c|}{$\begin{array}{c}\text { Chest X ray } \\
\text { Cardiomegaly }\end{array}$}} \\
\hline & \multirow{2}{*}{$\begin{array}{l}\text { Small voltage } \\
\text { complexes }\end{array}$} & \multirow{2}{*}{$\begin{array}{l}\text { Brady } \\
\text { cardia }\end{array}$} & \multirow{2}{*}{$\begin{array}{c}\text { ST-T } \\
\text { changes }\end{array}$} & \multirow{2}{*}{$\begin{array}{l}\text { Conduction } \\
\text { defects }\end{array}$} & & \\
\hline & & & & & Present & Absent \\
\hline Grade I & 1 & 0 & 2 & 0 & 0 & 11 \\
\hline Grade II & 0 & 0 & 0 & 0 & 0 & 8 \\
\hline Grade III & 1 & 0 & 1 & 3 & 0 & 10 \\
\hline Grade IV & 1 & 1 & 1 & 1 & 1 & 7 \\
\hline Grade V & 4 & 6 & 2 & 1 & 3 & 10 \\
\hline
\end{tabular}




\section{ORIGINAL ARTICLE}

\begin{tabular}{|c|c|c|c|c|c|c|c|}
\hline & & \multicolumn{5}{|c|}{ Grade of hypothyroidism } & \\
\hline \multirow{2}{*}{\multicolumn{2}{|c|}{$\begin{array}{c}\text { Diastolic } \\
\text { dysfunction }\end{array}$}} & \multirow{3}{*}{$\begin{array}{c}\text { I } \\
5-10 \mu \\
\mathrm{IU} / \mathrm{ml}\end{array}$} & \multirow{3}{*}{$\begin{array}{c}\text { II } \\
10-20 \\
\mu \mathrm{IU} / \mathrm{ml}\end{array}$} & \multirow{3}{*}{$\begin{array}{c}\text { III } \\
>20 \mu \\
\text { IU } / \mathrm{ml}\end{array}$} & \multicolumn{2}{|c|}{ TSH low, T4 low } & \\
\hline & & & & & IV & $\mathbf{V}$ & \\
\hline & & & & & $\begin{array}{c}\mathrm{T} 3 \\
>60 \mathrm{ng} / \mathrm{ml} \\
\end{array}$ & $\begin{array}{c}\mathrm{T} 3 \\
<60 \mathrm{ng} / \mathrm{ml} \\
\end{array}$ & \\
\hline \multirow{2}{*}{ Absent } & Count & 11 & 8 & 9 & 4 & 9 & 41 \\
\hline & $(\%)$ & 26.8 & 19.5 & 22.0 & 9.8 & 22 & 100 \\
\hline \multirow{2}{*}{$\begin{array}{c}\text { Grade } \\
1\end{array}$} & Count & 0 & 0 & 1 & 4 & 1 & 6 \\
\hline & $(\%)$ & 0 & 0 & 16.7 & 66.7 & 16.7 & 100 \\
\hline \multirow{2}{*}{$\begin{array}{c}\text { Grade } \\
2\end{array}$} & Count & 0 & 0 & 0 & 0 & 1 & 1 \\
\hline & $(\%)$ & 0 & 0 & 0 & 0 & 100 & 100 \\
\hline \multirow{2}{*}{$\begin{array}{c}\text { Grade } \\
3\end{array}$} & Count & 0 & 0 & 0 & 0 & 2 & 2 \\
\hline & $(\%)$ & 0 & 0 & 0 & 0 & 100 & 100 \\
\hline \multirow[t]{2}{*}{ Total } & Count & 11 & 8 & 10 & 8 & 13 & 50 \\
\hline & $(\%)$ & 22 & 16 & 20 & 16 & 26 & 100 \\
\hline
\end{tabular}

Table 2: Association between grade of hypothyroidism and diastolic dysfunction

- Chi-Square Tests:

\begin{tabular}{|c|c|c|c|}
\hline & Value & df & Asymp. Sig. (2-sided) \\
\hline Pearson Chi-Square & $22.766(\mathrm{a})$ & 12 & .030 \\
\hline Linear-by-Linear Association & 7.944 & 1 & $.005^{*}$ \\
\hline No. of Valid Cases & 50 & & \\
\hline
\end{tabular}

a: 15 cells (75.0\%) have expected count less than 5. The minimum expected count is 16 .

* Correlation is significant at the 0.05 level.

a) Descriptive statistics.

\begin{tabular}{|c|c|c|c|c|c|}
\hline $\begin{array}{c}\text { Grade of } \\
\text { hypothyroidism }\end{array}$ & I & II & III & IV & V \\
\hline IVRT & $73.09 \pm 4.28$ & $73.75 \pm 5.497$ & $76.50 \pm 11.578$ & $97.13 \pm 18.597$ & $80.54 \pm 16.076$ \\
\hline $\mathrm{dt}$ & $191 \pm 20.734$ & $200.63 \pm 25.88$ & $210.90 \pm 31.74$ & $247.88 \pm 49.41$ & $190.08 \pm 45.39$ \\
\hline $\mathrm{TSH}$ & $8.75 \pm 0.82$ & $14.67 \pm 3.46$ & $49.90 \pm 31.03$ & $117.10 \pm 27.94$ & $102.36 \pm 43.17$ \\
\hline \multicolumn{5}{|c|}{ Table 3: Association between isovolumic ventricular relaxation, } \\
deceleration time and grade of hypothyroidism
\end{tabular}

IVRT: Isovolumic ventricular relaxation time. $\mathrm{dt}$ : Deceleration time. 


\section{ORIGINAL ARTICLE}

TSH: Thyroid stimulating hormone.

b) Correlations.

\begin{tabular}{|c|c|c|c|}
\hline & & IVRT(ms) & Grade of Hypothyroidism \\
\hline \multirow{3}{*}{ IVRT(ms) } & Pearson correlation & 1 & .328 \\
\cline { 2 - 4 } & Sig. (2-tailed) & & $0.020^{*}$ \\
\cline { 2 - 4 } & $\mathrm{N}$ & 50 & 50 \\
\hline \multirow{3}{*}{ Grade of hypothyroidism } & Pearson correlation & .328 & 1 \\
\cline { 2 - 4 } & Sig. (2-tailed) & $0.020^{*}$ & \\
\cline { 2 - 4 } & $\mathrm{N}$ & 50 & 50 \\
\hline
\end{tabular}

* Correlation is significant at the 0.05 level (2-tailed) ms: milliseconds

a) Descriptive statistics.

\begin{tabular}{|c|c|c|c|c|}
\hline $\begin{array}{c}\text { Grade of } \\
\text { hypothyroidism }\end{array}$ & & $\begin{array}{c}\text { End systolic } \\
\text { diameter of LV } \\
\text { (centimeters) }\end{array}$ & $\begin{array}{l}\text { End diastolic } \\
\text { diameter of LV } \\
\text { (centimeters) }\end{array}$ & $\begin{array}{c}\text { Interventricular } \\
\text { septum thickness } \\
\text { (centimeters) }\end{array}$ \\
\hline \multirow{3}{*}{ 5-10 microlU $/ \mathrm{ml}$} & Mean & 3.1636 & 4.2573 & 1.0100 \\
\hline & $\mathrm{N}$ & 11 & 11 & 11 \\
\hline & SD & .70608 & .53130 & .05422 \\
\hline \multirow{3}{*}{$\begin{array}{c}10-20 \\
\mathrm{microlU} / \mathrm{ml}\end{array}$} & Mean & 2.8513 & 4.2250 & .9963 \\
\hline & $\mathrm{N}$ & 8 & 8 & 8 \\
\hline & SD & .23997 & .38822 & .05370 \\
\hline \multirow{3}{*}{$>20 \mathrm{microIU} / \mathrm{ml}$} & Mean & 2.8260 & 4.1710 & 1.0070 \\
\hline & $\mathrm{N}$ & 10 & 10 & 10 \\
\hline & SD & .36864 & .34892 & .07573 \\
\hline \multirow{3}{*}{$\begin{array}{c}\text { TSH low, t4 low, } \\
\text { normal t3 } \\
(>60 \mathrm{ng} / \mathrm{ml})\end{array}$} & Mean & 2.9825 & 4.3888 & .9975 \\
\hline & $\mathrm{N}$ & 8 & 8 & 8 \\
\hline & SD & .37625 & .51440 & .02188 \\
\hline \multirow{3}{*}{$\begin{array}{c}\text { TSH low, t4 low, } \\
\text { t3 low } \\
(<60 \mathrm{ng} / \mathrm{ml})\end{array}$} & Mean & 2.8746 & 4.3462 & 1.2546 \\
\hline & $\mathrm{N}$ & 13 & 13 & 13 \\
\hline & SD & .60156 & .44836 & .14864 \\
\hline \multirow{3}{*}{ Total } & Mean & 2.9420 & 4.2790 & 1.0688 \\
\hline & $\mathbf{N}$ & 50 & 50 & $\mathbf{5 0}$ \\
\hline & SD & .51026 & .44120 & .14124 \\
\hline
\end{tabular}

Table 4: Association between grade of hypothyroidism and Left Ventricular dimensions

b) Correlations. 
ORIGINAL ARTICLE

\begin{tabular}{|c|c|c|c|c|c|}
\hline & & $\begin{array}{c}\text { Grade of } \\
\text { hypothyroidism }\end{array}$ & $\begin{array}{l}\text { IVS thickness } \\
\text { (cm) }\end{array}$ & $\begin{array}{c}\text { EDD } \\
\text { LV } \\
(\mathrm{cm})\end{array}$ & $\begin{array}{c}\text { ESD of } \\
\text { LV } \\
(\mathrm{cm})\end{array}$ \\
\hline \multirow{3}{*}{$\begin{array}{c}\text { Grade of } \\
\text { hypothyroidism }\end{array}$} & $\begin{array}{c}\text { Pearson } \\
\text { Correlation }\end{array}$ & 1 & $.587(* *)$ & .108 & -.148 \\
\hline & Sig. (2-tailed) & & .000 & .454 & .306 \\
\hline & $\mathrm{N}$ & 50 & 50 & 50 & 50 \\
\hline \multirow{3}{*}{$\begin{array}{l}\text { IVS thickness } \\
(\mathrm{cm})\end{array}$} & $\begin{array}{l}\text { Pearson } \\
\text { Correlation }\end{array}$ & $.587\left({ }^{* *}\right)$ & 1 & .045 & -.086 \\
\hline & Sig. (2-tailed) & .000 & & .754 & .554 \\
\hline & $\mathrm{N}$ & 50 & 50 & 50 & 50 \\
\hline \multirow{3}{*}{$\begin{array}{l}\text { EDD LV } \\
(\mathrm{cm})\end{array}$} & $\begin{array}{c}\text { Pearson } \\
\text { Correlation } \\
\end{array}$ & & & & \\
\hline & Sig. (2-tailed) & .108 & .045 & 1 & $.503(* *)$ \\
\hline & $\mathrm{N}$ & .454 & .754 & & .000 \\
\hline \multirow{3}{*}{$\begin{array}{l}\text { ESD of LV } \\
\quad(\mathrm{cm})\end{array}$} & $\begin{array}{c}\text { Pearson } \\
\text { Correlation }\end{array}$ & 50 & 50 & 50 & 50 \\
\hline & Sig. (2-tailed) & & & & \\
\hline & $\mathrm{N}$ & & & & \\
\hline
\end{tabular}

** Correlation is significant at the 0.01 level (2-tailed).

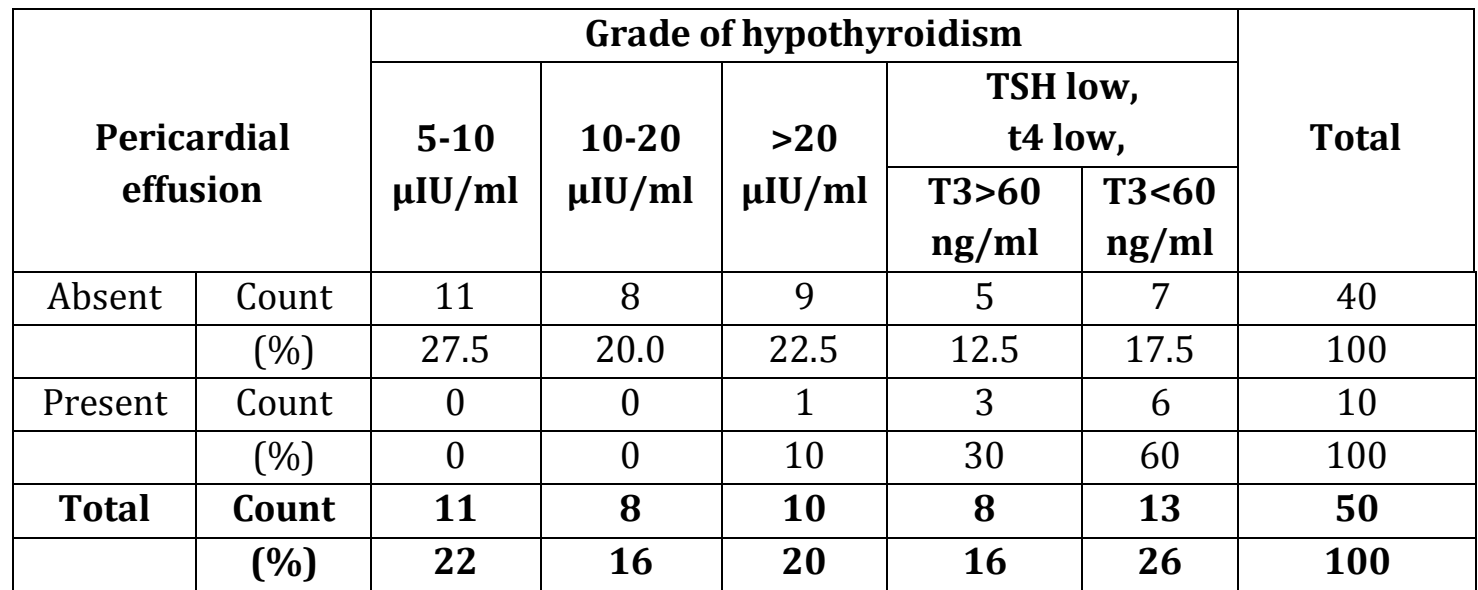

Table 5: Association between grade of hypothyroidism and Pericardial Effusion

\begin{tabular}{|c|c|c|c|}
\hline & Value & df & Asymp. Sig. (2-sided) \\
\hline Pearson Chi-Square & $12.464(\mathrm{a})$ & 4 & .014 \\
\hline Likelihood Ratio & 15.009 & 4 & .005 \\
\hline N of Valid Cases & 50 & & \\
\hline
\end{tabular}

a 5 cells (50.0\%) have expected count less than 5 .

The minimum expected count is 1.60 . 


\section{ORIGINAL ARTICLE}

\begin{tabular}{|c|c|c|c|c|c|c|c|c|c|c|c|c|c|c|c|c|}
\hline \multirow{3}{*}{$\begin{array}{l}\text { Sl. } \\
\text { No. }\end{array}$} & \multirow{2}{*}{\multicolumn{2}{|c|}{$\begin{array}{l}\text { LVIDs } \\
\text { (cm) }\end{array}$}} & \multirow{2}{*}{\multicolumn{2}{|c|}{$\begin{array}{l}\text { LVIDd } \\
\text { (cm) }\end{array}$}} & \multirow{2}{*}{\multicolumn{2}{|c|}{$\begin{array}{l}\text { IVS } \\
\text { (cm) }\end{array}$}} & \multicolumn{6}{|c|}{$\begin{array}{l}\text { LV Diastolic } \\
\text { Dysfunction }\end{array}$} & \multirow{2}{*}{\multicolumn{2}{|c|}{$\begin{array}{c}\text { Ejection } \\
\text { Fraction } \\
(\%)\end{array}$}} & \multirow{2}{*}{\multicolumn{2}{|c|}{$\begin{array}{c}\text { Pericardial } \\
\text { Effusion }\end{array}$}} \\
\hline & & & & & & & \multicolumn{2}{|c|}{ E/A } & \multicolumn{2}{|c|}{$\begin{array}{l}\text { IVRT } \\
\text { (ms) }\end{array}$} & \multicolumn{2}{|c|}{$\begin{array}{c}\text { Dt } \\
(\mathrm{ms})\end{array}$} & & & & \\
\hline & B & $\mathbf{A}$ & B & $\mathbf{A}$ & B & $\mathbf{A}$ & B & $\mathbf{A}$ & B & A & B & A & B & A & B & $\mathbf{A}$ \\
\hline 1 & 4 & 3.7 & 5.2 & 4.9 & 1 & 0.7 & 2.1 & 0.8 & 48 & 108 & 120 & 300 & 58.3 & 60 & Large & $\begin{array}{l}\text { Mode } \\
\text { rate }\end{array}$ \\
\hline 2 & 3.5 & 3.2 & 4.7 & 4.3 & 1 & 0.8 & 1.2 & 0.9 & 82 & 82 & 167 & 203 & 55 & 62 & $\begin{array}{l}\text { Mode } \\
\text { rate }\end{array}$ & $\mathrm{N}$ \\
\hline 3 & 2.7 & 2.5 & 4.2 & 4.0 & 0.9 & 0.9 & 0.7 & 1.1 & 104 & 83 & 300 & 238 & 68 & 67 & Mild & $\mathrm{N}$ \\
\hline 4 & 2.8 & 3.0 & 4.5 & 4.6 & 1 & 0.8 & 2 & 0.9 & 56 & 84 & 132 & 178 & 60 & 62 & $\begin{array}{l}\text { Mode } \\
\text { rate }\end{array}$ & $\mathrm{N}$ \\
\hline 5 & 2.5 & 2.6 & 3.7 & 3.7 & 1.1 & 1.0 & 0.6 & 1.0 & 107 & 77 & 278 & 237 & 58 & 59 & $\mathrm{~N}$ & $\mathrm{~N}$ \\
\hline 6 & 2.8 & 2.6 & 4.1 & 3.8 & 0.7 & 0.7 & 1.2 & 1.2 & 77 & 78 & 183 & 178 & 60 & 61 & Mild & $\mathrm{N}$ \\
\hline 7 & 3.2 & 3.1 & 4.5 & 4.5 & 1.3 & 1.1 & 1.2 & 0.8 & 68 & 98 & 197 & 257 & 59 & 57 & $\mathrm{~N}$ & $\mathrm{~N}$ \\
\hline 8 & 4.7 & 3.2 & 3.4 & 4.5 & 1 & 0.8 & 1.1 & 1.1 & 63 & 66 & 172 & 170 & 62.6 & 61 & $\mathrm{~N}$ & $\mathrm{~N}$ \\
\hline 9 & 2.8 & 2.7 & 4.3 & 4.3 & 0.8 & 0.8 & 0.6 & 0.9 & 100 & 92 & 267 & 240 & 58 & 60 & Mild & $\mathrm{N}$ \\
\hline 10 & 2.7 & 2.5 & 4.2 & 4.0 & 0.9 & 0.8 & 0.7 & 1.1 & 104 & 83 & 300 & 238 & 68 & 67 & Mild & $\mathrm{N}$ \\
\hline
\end{tabular}

*B: before; A: after.

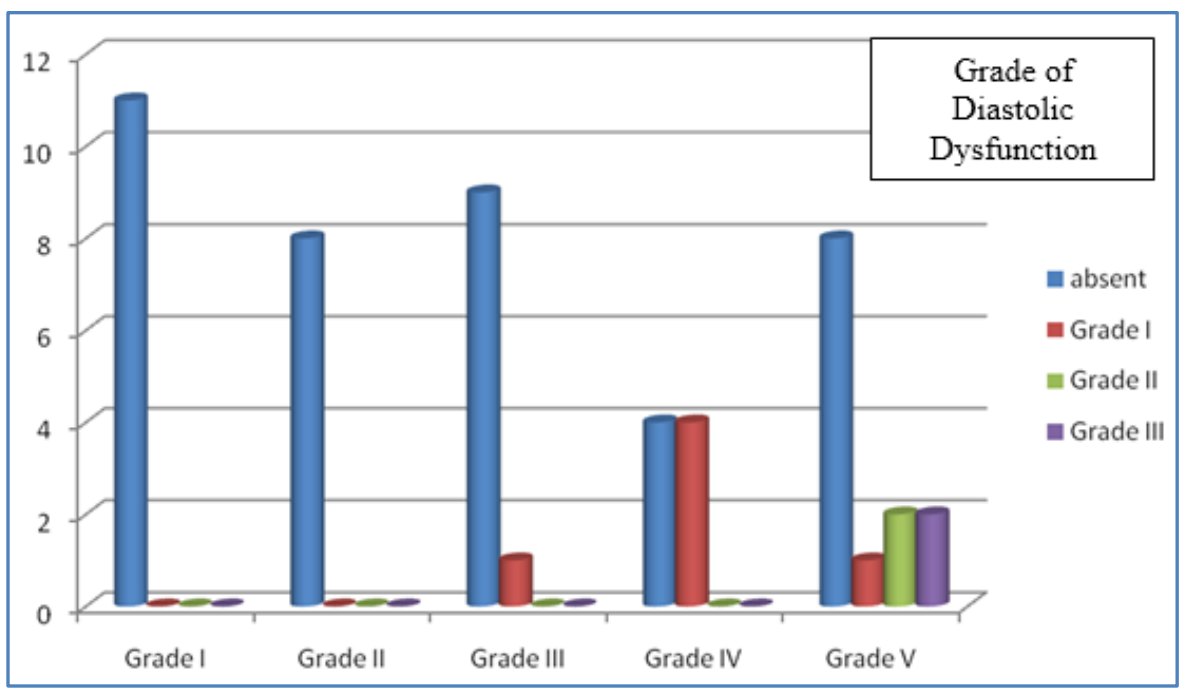

Bar Diagram 1 


\section{ORIGINAL ARTICLE}

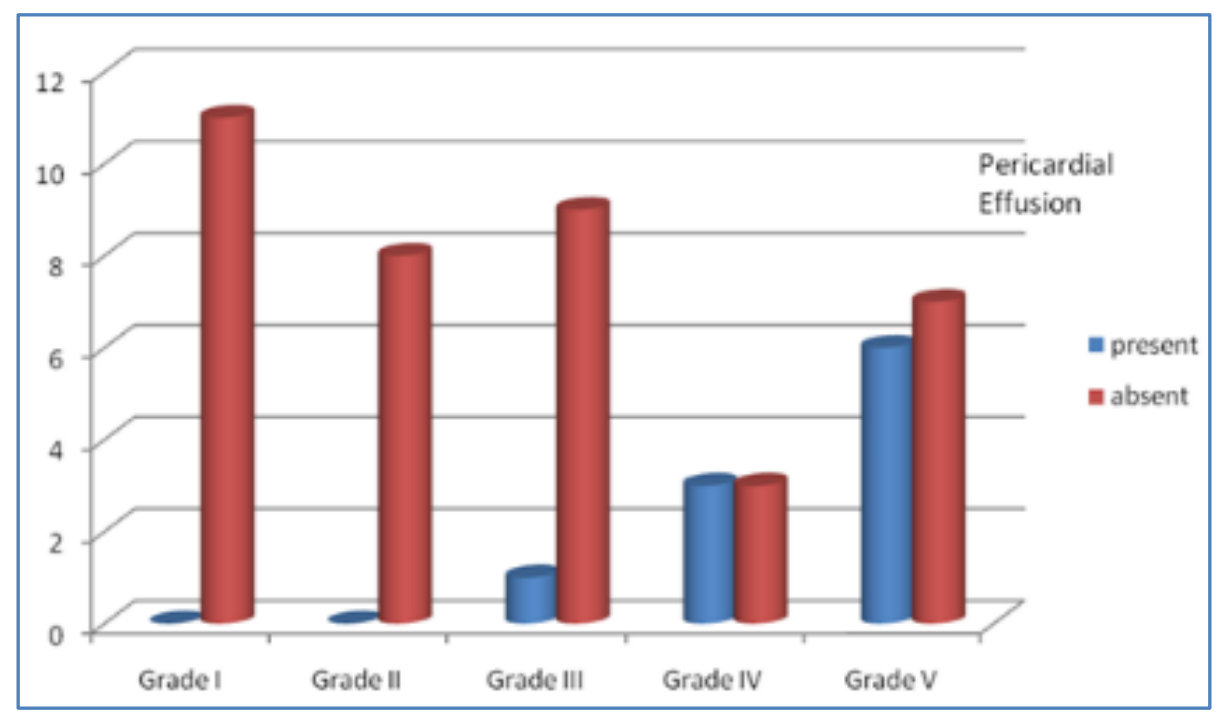

Bar Diagram 2

\section{AUTHORS:}

1. Kotha Sindhoora

2. Khandeparkar Viraj

3. Velho G. Rachita

4. Cacodcar Jagadish

\section{PARTICULARS OF CONTRIBUTORS:}

1. Senior Resident, Department of Medicine, Goa Medical College.

2. Associate Professor, Department of Medicine, Goa Medical College.

3. Associate Professor, Department of Medicine, Goa Medical College.

FINANCIAL OR OTHER

COMPETING INTERESTS: None
4. Associate Professor, Department of Medicine, Goa Medical College.

\section{NAME ADDRESS EMAIL ID OF THE} CORRESPONDING AUTHOR:

Dr. Kotha Sindhoora,

H. No. 22/404/3,

36 LA Oceana II,

Opp: Telephone Exchange, University Road, Dona Paula,

Gao-403002.

E-mail: sindhoora.hi@gmail.com

Date of Submission: 10/07/2015.

Date of Peer Review: 11/07/2015.

Date of Acceptance: 25/07/2015.

Date of Publishing: 31/07/2015. 